\title{
A NOVA METAFÍsICA E A COMPREENSÃo DA RELIGIÃo
}

A new Metaphysics and the understanding of religion

Manfredo Araújo de Oliveira *

Resumo: Depois das diferentes teorias da secularização e da extraordinária "irrupção dos deuses" no nosso século, a religião se tornou objeto fundamental de investigação de inúmeras ciências e de inúmeras propostas filosóficas. Como compreende a filosofia o fenômeno religioso? $O$ que especifica sua consideração da religião? A filosofia estrutural sistemática de L.B. Puntel a considera a partir de dois níveis que ele denomina enfoques. $O$ enfoque 1 considera o fenômeno religioso a partir do espírito humano enquanto intencionalmente coextensivo com o Ser em seu todo. $\mathrm{O}$ ser humano tende a entender em sua vida concreta a posição que ele ocupa no universo e articular uma forma correspondente à sua vida através da referência explícita a esse espaço abrangente entendendo-o como uma inteligência suprema derradeira e vontade suprema derradeira. $\mathrm{O}$ enfoque 2 procura esclarecer a partir de si mesma a dimensão última ou suprema antes mencionada como o ponto de referência fundamental e absolutamente central da religião.

Palavras-chave: Religião. Secularização. Filosofia estrutural-sistemática. Ser em seu todo. L.B. Puntel.

Abstract: After the different theories of secularization and the extraordinary "eruption of the gods" in our century, religion has become a major object of research in countless sciences and philosophical proposals. How does philoso-

* Professor titular do Departamento de Filosofia da Universidade Federal do Ceará. Artigo recebido em 23/06/2020 e aprovado para publicação em 20/10/2020. 
phy understand the religious phenomenon? What specifies its consideration of religion? L. B. Puntel's structural-systematic philosophy considers religion at two levels which he calls approaches. For the first one, the religious phenomenon comes from the human spirit itself and is seen as intentionally coextensive with the Being as a whole. Human beings, in their concrete lives, tend to understand their position in the universe and to articulate a form of life that corresponds to its explicit reference to this all-encompassing space, understanding it as anhe ultimate supreme intelligence and will. The second approach seeks to clarify from within itself the ultimate or supreme dimension mentioned above as being the fundamental point of reference, one that is absolutely central to religion.

Keywords: Religion. Secularization. Structural Systematic Philosophy. Being as a whole. L.B. Puntel.

\title{
1. Localização da temática na filosofia estrutural- sistemática
}

\begin{abstract}
$\longrightarrow$ omo compreender filosoficamente o fenômeno religioso? Esta questão é decisiva sobretudo levando em consideração tanto as inúmeras ao fato fundamental de que a religião se tornou hoje objeto de investigação de diferentes ciências ${ }^{1}$. O que especifica uma compreensão filosófica da religião? Onde na filosofia se situa propriamente a consideração da religião? Que pressupõe filosoficamente tal consideração? A posição de Puntel se diferencia radicalmente do que se faz hoje em relação à compreensão da religião em primeiro lugar por tratar expressamente destes pressupostos.
\end{abstract}

Puntel se põe no contexto da tese básica que caracterizou nossa tradição de pensamento: a filosofia parte da concepção fundamental de que ela é uma teoria, ou seja, uma atividade humana que se diferencia de outras atividades humanas justamente porque sua meta básica é a articulação e a apresentação de teoria, cuja especificidade é a apreensão da verdade do que investiga. ${ }^{2} \mathrm{O}$ que diferencia a filosofia de outras atividades teóricas é que ela se entendeu a si mesma como um saber abrangente, um saber de caráter universal, irrestrito, uma ciência universal, a expressão de uma

\footnotetext{
${ }^{1}$ Cf. MAC DOWELL J. A., Filosofia da Religião: sua centralidade e atualidade no pensamento filosófico (2011), p. 17-49. Mac Dowell defende aqui que no contexto secularizante da cultura moderna, é inegável a presença marcante do fenômeno religioso no panorama cultural contemporâneo. Observa-se aqui também nas últimas décadas um ressurgimento significativo da Filosofia da Religião, tanto na Europa continental quanto no ambiente anglo-americano. Cf. também: MAC DOWELL J. A, Religião, Modernização e Secularização, in: MAIA A. G. B. I OLIVEIRA G. P. (orgs.), Filosofia, Religião e Secularização, 2015, p. 30-60.

${ }^{2}$ Cf. PUNTEL L. B., Estrutura e ser. Um quadro referencial teórico para uma filosofia sistemática. São Leopoldo: Ed. Unisinos, 2008, p. 97 e ss., de agora em diante citado como Estrutura e ser.
} 
compreensão abrangente das estruturas fundamentais da realidade como um todo ${ }^{3}$.

O objetivo básico da posição de Puntel é recuperar este caráter teórico, sistemático e universal da filosofia, cujo nível supremo é uma Teoria do Ser como tal e em seu todo. Com isto, a "dimensão teórica, sistemática e universal" se repõe no centro do pensamento filosófico o que significa dizer que ele se contrapõe de uma maneira radical a uma das tendências fundamentais do pensamento contemporâneo. ${ }^{4}$

A teoricidade revela-se, assim, como a primeira característica fundamental do pensamento filosófico que é "sistemático". Esta concepção global da realidade apresenta dois componentes básicos: a completude da temática e a tematização das conexões entre todos os componentes temáticos num todo coerente. Isto em contraposição às ciências que têm um universo restrito de discurso como seu objeto e, enquanto tal, são ciências particulares.

Numa palavra, o próprio da investigação filosófica é que seu domínio de investigação é absolutamente irrestrito. Assim, seu nível supremo de investigação, como veremos, é a dimensão derradeira que Puntel denomina "Ser" entendido em seu conteúdo mínimo como "não nada". "Nesse sentido "Ser" nomeia a mais fundamental de todas as dimensões, a dimensão que engloba, compreende e abrange absolutamente todas as espécies e formas do que é, isto é, de "Ser": todos os entes, concretos e abstratos, gerais e particulares, possíveis e reais, etc." ${ }^{5}$ Daí a precaução que o filósofo deve ter em relação às ciências. ${ }^{6}$.

Uma Metafísica Estrutural, como a que, em última instância, é proposta aqui, não se articula como um sistema axiomaticamente concebido que parte de princípios e axiomas fundamentais a partir de onde vai derivando novos conhecimentos, mas antes se organiza como uma espécie de "rede". O quadro teórico da filosofia é, então, de alta complexidade, constituído por

${ }^{3}$ Cf. HERRERO F. J., Ser e Deus na filosofia sistemático-estrutural de Puntel, in: Síntese, 2012, v. 39, n. 124, p. 210: “...no panorama atual de fragmentação, e em muitos casos de puro relativismo, Puntel consegue redescobrir a intenção original da filosofia e demonstrá-la com todos os meios e recursos conceituais que a mesma filosofia atual oferece".

${ }^{4}$ Cf. HERRERO F. J., O desafio que a teoria sistemático-estrutural de Puntel coloca à filosofia atual, in: Kriterion, 2012, n. 125, p. 8: “Cada enfoque mostra apenas um fragmento ou, como se costuma dizer, uma aproximação. Mas o característico dessa fragmentação é que ela é defendida como algo inevitável e que leva consigo a consequência de que a tematização do todo é impossível".

${ }^{5}$ PUNTEL L. B., A pergunta "Por que existe alguma coisa em vez de nada?" faz sentido?, in: ROHDEN L. / VALLS A. (orgs.), Entre a Filosofia Dialética e a Gestão. Festschrift em homenagem ao Pe. Marcelo Aquino, S.J., 2018, p.31.

${ }^{6}$ Cf. PUNTEL L. B., Metaphysics_ 5 Questions, in: STEGLICH-PETERSEN A., Metaphysics_ 5 questions, Automatic Press / VIP, 2010, p. 99: “... special metaphysics should be extremely careful to avoid entering the proper spheres of other academic disciplines, most especially the natural sciences". 
numerosos quadros particulares "que devem ser entendidos como estágios do processo que leva à constituição do quadro sistemático completo". ${ }^{7}$

Assim, esta análise inicia com uma concepção minimal (quadro teórico ainda abstrato) da filosofia sistemática. No decorrer do processo de concretização e determinação do quadro teórico são aduzidos novos elementos na direção de sua determinação plena. A teoria é estruturada, como diz A. White (Rumo a uma teoria filosófica de tudo, 2016, 28), como uma rede holística de sentenças marcada por um crescimento de "densidade" que é acompanhado por um crescimento de "refinamento". Isto expressa um aumento de inteligibilidade e de coerência. É neste horizonte que Puntel elabora uma definição programática de uma teoria filosófica como ciência universal, "como teoria das estruturas universais do universo irrestrito do discurso". 8 O universo do discurso é para Puntel "o dado abrangente no sentido de: o dado a ser compreendido ou a ser explicado da filosofia, isto é, tudo aquilo com que a teoria filosófica pode e deve se ocupar". ${ }^{9}$ Numa palavra, "dado" significa aqui algo linguisticamente articulado, o conteúdo informativo de uma sentença.

O conceito de teoria se refere em primeiro lugar às ciências formais e empíricas. A filosofia não é uma ciência formal ou empírica, embora contenha tanto elementos formais como empíricos. Daí a pergunta central: como articular um conceito de teoria filosófica? A teoria é a forma de discurso metódico e rigorosamente ordenado que é composto de sentenças puramente declarativas, sentenças da forma: "é o caso que assim e assim". Este operador teórico é um operador não limitável por quaisquer fatores apesar de filósofos muitas vezes o particularizarem. A atividade teórica e seu produto têm a ver com o mundo entendido como a totalidade irrestrita dos "objetos" ou "campos" ou "âmbitos": uma teoria explicita como o mundo se comporta, ela articula algo sobre algo no mundo. ${ }^{10}$

Numa palavra, na teoria, em contraposição à "comunicação" na vida quotidiana, é a "coisa" que passa para o primeiro plano. É por esta razão que a "linguagem natural" se manifesta inconveniente para uma teoria filosófica e precisa ser substituída por uma linguagem adequada à sua tarefa própria. Exprimir a inteligibilidade de algo é a tarefa específica de todo empreendimento teórico. Compreender e realidade constituem, assim, as duas dimensões essenciais de uma teoria.

\footnotetext{
7 PUNTEL L. B., Ser e Deus. Um enfoque sistemático em confronto com M. Heidegger, E. Lévinas e J-L. Marion, São Leopoldo: Ed. Unisinos, 2011, p. 147. De agora em diante citado como Ser e Deus.

${ }^{8}$ PUNTEL L. B., Ser e Deus, p. 147.

${ }^{9}$ PUNTEL L. B., Ser e Deus, p. 147.

${ }^{10}$ PUNTEL L. B, A filosofia como discurso sistemático. Diálogo com Emmanuel Tourpe sobre os fundamentos de uma teoria dos entes, do Ser e do Absoluto, São Leopoldo: Editora Unisinos, 2015, p. 50. De agora em diante citado como A filosofia como discurso sistemático.
} 
A primeira tarefa da filosofia consiste, então, no esclarecimento dos componentes irrenunciáveis da teoricidade pressupostos no tratamento de qualquer questão posta à filosofia: "Sem essas pressuposições básicas, não é possível compreender nada, tudo permanece vago e indeterminado" ${ }^{11}$ Trata-se, assim, de esclarecer os pressupostos te da teórico-metodológicos da filosofia que reflete sobre seus próprios pressupostos, condições de expressão das "coisas mesmas". Assim, o primeiro momento de uma teoria filosófica consiste na tematização da dimensão das estruturas fundamentais que são os elementos pressupostos na elaboração de qualquer teoria filosófica. ${ }^{12} \mathrm{O}$ conjunto de todos os componentes essenciais que constituem uma teoria é o que Puntel denomina de "quadro referencial teórico".

O caráter irrecusável de um quadro teórico se demonstra pelo fato de que toda proposição teórica, toda argumentação e toda teoria só têm sentido, ou seja, um status determinado e claro, e, portanto, é inteligível e avaliável, na medida em que se encontra situada no seio de um quadro referencial teórico. Em tudo o que faz um filósofo, ele pressupõe e utiliza um quadro referencial teórico mesmo sem consciência disto. A tematização dos momentos essenciais do quadro teórico constitui, portanto, o fundamento de uma filosofia sistemática. A fonte dos inúmeros erros cometidos pelos filósofos em todas as épocas consiste para Puntel precisamente na falta de consideração ou mesmo total desconhecimento deste elemento central. ${ }^{13}$ Daí a premência da elaboração de um quadro referencial teórico e seus momentos essenciais, as estruturas. Quais são seus momentos fundamentais? Para Puntel basicamente três: lógica, semântica e ontologia. ${ }^{14}$ "O fato de haver três planos ou espécies de estruturas não é derivável a priori, mas, antes, o resultado de um exame compreensivo de todos os elementos que estão em jogo de uma ou de outra forma numa teoria filosófica". ${ }^{15}$

Para o exame de qualquer questão filosófica temos, então, que dispor de uma linguagem, porque uma teoria tem que ser articulada. Por isto, “...a linguagem é absolutamente central para a filosofia: ela é ponto de partida e ponto de referência incontornável de toda exposição filosófica" ${ }^{16} \mathrm{~A}$ linguagem é formada por sentenças que constituem a unidade linguística fundamental. Nenhuma sentença se encontra em isolamento pleno já que cada sentença pertence à linguagem enquanto o conjunto de todas as sentenças. Por isso, cada sentença estabelece as mais diversas conexões com outras sentenças.

\footnotetext{
${ }^{11}$ HERRERO F. J., Deus na filosofia sistemático-estrutural de Puntel, 2012, p. 210.

12 PUNTEL L. B., A filosofia como discurso sistemático, p. 102.

13 PUNTEL L. B., Ser e Deus, p. 146, A filosofia como discurso sistemático, p. 35.

14 PUNTEL L. B., A filosofia como discurso sistemático, p. 64.

15 PUNTEL L. B., Ser e Deus, p. 157.

16 PUNTEL L. B., Ser e Deus, p. 152; A filosofia como discurso sistemático, p. 66.
} 
Ora, o todo destas relações é determinado pelo que Puntel denomina de "estruturas lógicas" que são as mais fundamentais de todas as estruturas interconectadas entre si. Elas são coextensivas com a realidade. São normalmente consideradas abstratas e com razão no sentido de que sendo ilimitadas abstraem de toda particularidade. ${ }^{17}$ Estas estruturas formais não são apenas temas da filosofia, mas "elas constituem um instrumento expositivo para as teorias filosóficas".$^{18}$ Elas são assim as mais universais, estruturam toda e qualquer sentença teórica e consequentemente toda proposição expressa nas sentenças e por isto estruturam as coisas mesmas " que são o "lado" ontológico das proposições expressas pelas sentenças teóricas". ${ }^{19}$ Por esta razão, em contraposição à tese hegemônica de que lógica e ontologia são duas dimensões completamente distintas, Puntel articula uma consequência fundamental desta postura: as estruturas lógicas/ matemáticas são interpretadas ontologicamente.

Assim, “... o sentido do emprego de itens lógicos/matemáticos consiste em precisamente esclarecer o que acontece no plano ontológico; seria absurdo admitir que este emprego teria o sentido de construir conexões somente "na nossa mente". ${ }^{20}$ "Essa "camada" é, por assim dizer, a dimensão de todas as interconexões, de todos os modos de configuração de tudo o que ocorre no universo irrestrito do discurso" ${ }^{21}$ Estas estruturas logicas/matemáticas são, na expressão de Russell, justamente os "traços mais universais possíveis da realidade. Em outros termos, essas estruturas são a dimensão mais universal da ontologia (e da teoria do Ser)".$^{22}$ Por isso constituem a textura interna de cada discurso e de cada entidade.

Por outro lado, cada sentença teórica é essencialmente "semanticamente" estruturada, possui um "expressum", um conteúdo informacional. Sua consideração parte de uma tese básica: a da fundamentalidade e da centralidade da semântica na linguagem já que ela é condição de inteligibilidade das duas outras esferas de determinação da linguagem: o contexto da vida cotidiana e a esfera pragmática. Por isso constituem "como que o eixo sobre o qual gira tudo na formação da teoria filosófica".$^{23}$ Elas são um nível intermediador: possuem um "donde" por serem o expresso de sentenças; mas, têm também um "para onde": apontam para além delas mesmas, expressam o plano ontológico. Quando plenamente determinadas se identificam com o plano ontológico. Daí o axioma básico: semântica e ontologia são dois lados de uma mesma medalha.

\footnotetext{
${ }_{17}$ PUNTEL L. B., A filosofia como discurso sistemático, p. 65.

${ }^{18}$ PUNTEL L. B., Ser e Deus, p. 158.

${ }^{19}$ PUNTEL L.B., A filosofia como discurso sistemático, p. 64.

${ }^{20}$ PUNTEL L. B., Observações críticas sobre uma resenha de Guido Imaguire da obra: Estrutura e Ser, 2013, p. 52.

${ }^{21}$ PUNTEL L. B., Ser e Deus, p. 158.

22 PUNTEL L. B., A filosofia como discurso sistemático, p. 66.

${ }^{23}$ PUNTEL L. B., Ser e Deus, p. 158.
} 
A consideração das estruturas conteudísticas, as semânticas e ontológicas, ocorre através da discussão de duas questões centrais para toda a proposta: 1) A crítica à semântica tradicional, a "composicional", e a proposta de uma semântica alternativa, a semântica "contextual"; 2) A crítica à ontologia tradicional correspondente à essa semântica, a "ontologia substancialista", e a proposta de uma ontologia alternativa, uma "ontologia contextual". A semântica aqui exposta é uma versão forte (incompatível com o princípio de composicionalidade) do princípio do contexto de Frege. ${ }^{24}$ Parte-se do primado semântico da sentença, da tese de que a unidade linguística central não é a palavra, mas a sentença que é uma configuração, um todo a partir de onde os componentes subsentenciais podem ser compreendidos e explicados. Daí a formulação do princípio em Frege: "só no contexto de uma sentença as palavras significam algo" ${ }^{25}$

Já que os componentes subsentenciais se compreendem a partir da sentença eles podem ser eliminados (do ponto de vista semântico). Com isso, desaparece a estrutura sujeito/predicado típica de uma semântica composicional. Esta semântica é inaceitável por implicar numa ontologia substancialista que é inadmissível porque sua entidade básica é ininteligível. Substância é uma categoria dual: só se pode falar dela em conexão com as determinações que predicamos a ela. Se afastamos todas estas determinações, permanece apenas uma entidade inteiramente indeterminada, portanto, ininteligível.

As sentenças sem sujeito e predicado se denominam "sentenças primas", que se explicitam através do operador teórico "é o caso que assim e assim". O que é expresso por estas sentenças é uma "proposição prima", que quando verdadeira é idêntica a uma entidade do mundo, a um fato do mundo, um "fato primo" que é a única categoria ontológica admitida nesta filosofia. Fato primo é, então, qualquer entidade que é um elemento do mundo. Quando estas sentenças são verdadeiras elas exprimem uma proposição prima altamente complexa que é idêntica a uma "configuração" altamente complexa de fatos primos. Assim, as coisas do mundo, sobretudo os indivíduos humanos, são configurações de fatos primos. "Configuração" é o que propriamente substitui a categoria de substância.

As estruturas foram apresentadas em seus traços básicos. Agora se põe uma questão última neste nível da teoria: como estão as estruturas inter-relacionadas? Como pensar seu nexo? Essa questão é central para que se possa atingir o estatuto plenamente determinado do quadro teórico. Para Puntel é o conceito de verdade que dá a reposta a esta questão. ${ }^{26}$ Verdade é trabalhada aqui em duas perspectivas: semântica e ontológica. ${ }^{27}$

\footnotetext{
${ }^{24}$ PENCO C., Introdução à filosofia da linguagem, Petrópolis: Vozes: 2006, p. 61 e ss.

${ }^{25}$ Cf. FREGE G., Die Grundlagen der Arithmetik, Breslau: Koebner, 1884, citado aqui de acordo com a: Centenarausgabe, Hamburg: Meiner, 1986, § 62.

${ }^{26}$ OLIVEIRA M. A. de, A ontologia em debate no pensamento contemporâneo, 2014, p. 243-251.

27 PUNTEL L. B., Ser e Deus, p. 186-203, 295-326; Ser e Deus, p. 162-175; A filosofia como discurso sistemático, p. 83-96.
} 
Como foi visto, a linguagem se revela primeiramente como um sistema de signos ou símbolos, originariamente indeterminado ou subdeterminado. Semanticamente, trabalhar a questão da verdade significa, então, aclarar a questão da determinação, da passagem da indeterminidade para a determinidade completa da linguagem. Nesse nível, verdade significa o status plenamente determinado da linguagem, algo totalmente desconsiderado pelas teorias deflacionistas da verdade. Ontologicamente, a tese fundamental de Puntel é que uma sentença prima é verdadeira quando expressa uma proposição prima verdadeira. Uma proposição prima é verdadeira quando é idêntica a um fato mundano, portanto, a um componente do mundo. ${ }^{28}$ Numa palavra, verdade é em última instância uma relação de identidade entre linguagem e mundo, entre estrutura e universo do discurso.

\section{O lugar da religião na Sistemática do Mundo}

A apresentação da dimensão estrutural foi ainda abstrata porque não se tematizou sua segunda dimensão sempre pressuposta: o universo ilimitado do discurso. No passo teórico seguinte, “...o quadro referencial teórico anteriormente elaborado á aplicado à dimensão dos dados e por fim do grande dado". ${ }^{29}$ Mostra-se que o quadro teórico elaborado "pode servir de base para uma teoria do mundo e suas muitas partes"..$^{30}$ A diferença entre as duas, apresentada no início, era apenas de ordem metodológica. O que se mostra aqui é que a verdade do universo é resultado da junção entre a dimensão estrutural e o conjunto de dados.

A tarefa específica da filosofia agora consiste, então, em pôr em relação a dimensão estrutural e o universo do discurso, o universo dos diferentes domínios do mundo. Essa articulação de uma teoria dos entes é o que Puntel denomina de "Sistemática do Mundo". "A aplicação das estruturas parte de dados, que são crescentemente teorizados no sentido de serem integrados em conexões ou conectividades sempre mais abrangentes... indivíduos...; estes em domínios de ser (natureza anorgânica, mundo da vida, mundo humano...); todos os domínios numa conectividade mais abrangente chamada de mundo" ${ }^{31}$ Essa aplicação só é possível se entre

\footnotetext{
${ }^{28}$ A respeito da discussão atual sobre a proposição cf. IMAGUIRE G., Proposição, in: BRANQUINHO J./MURCHO D./GOMES N. G. (orgs.), Enciclopédia de termos lógico-filosóficos, 2006, p. 628-631. HANKS P. W., "Recent Work on Propositions", in: Philosophy Compass 4/3 (2009) p. 469-486. VIANA W. C., A filosofia estrutural-sistemática. Uma análise interpretativo-sistemática, 2019 , p. 199-229. A respeito das inúmeras discussões atuais a respeito da verdade enquanto identidade cf. VIANA W. C., A filosofia estrutural-sistemática, 2019, p. 263-301.

${ }^{29}$ A filosofia como discurso sistemático, 2015, p. 34.

${ }^{30}$ PUNTEL L. B., A filosofia como discurso sistemático, p. 104.

${ }^{31}$ PUNTEL L. P., Cirne-Lima e sua rejeição do "Deus de católicos e protestantes...", in: Síntese, Revista de Filosofia v. 36, n. 114, 2009, p. 48.
} 
ambas as dimensões for pressuposto algo fundamental em comum, uma unidade que primeiro possibilite a "conjunção de ambas". ${ }^{32}$ Daí a tese básica: há uma unidade originária entre estruturas e ser que é pressuposta como condição da aplicação. Essa unidade originária que abrange tanto a dimensão dos entes (do mundo) como a dimensão do intelecto/do espírito é o que que Puntel vai chamar de "Ser Primordial", isto é, como a conexão ou a unidade da dimensão teórica das estruturas e da dimensão do mundo.

\subsection{O fenômeno religioso a partir da compreensão do espírito humano enquanto coextensivo intencionalmente com o Ser em seu todo}

A tarefa aqui consiste primeiramente em esclarecer como as estruturas universais do universo irrestrito do discurso se especificam nestes diferentes campos. O pressuposto básico do ponto de vista teórico-metodológico da Sistemática do Mundo é que o quadro teórico elaborado "pode servir de base para uma teoria do mundo e suas muitas partes". ${ }^{33}$ Por isto, este momento da reflexão filosófica inicia com a consideração das muitas esferas do mundo e desemboca na pergunta pela totalidade dessas esferas, precisamente o "mundo" de que os diferentes domínios são parte de modo que o processo reflexivo conduz à tematização da pergunta por esta totalidade. Puntel realiza isto através da consideração de três grandes temas: 1) A teoria cosmológico-física; 2) O grande fenômeno da religião ou das religiões e seu desenvolvimento histórico; 3) A história mundial.

Na consideração do fenômeno religioso, Puntel começa com a afirmação de que a religião sempre teve uma importância fundamental em todas as épocas da história da humanidade e que, em nossa época, em que muitos pensavam que ele teria perdido qualquer significação para a vida e a cultura dos seres humanos, experimentamos um impulso novo e inesperado de uma multiplicidade de experiências religiosas ${ }^{34}$ e, sobretudo, através de muitas pesquisas em diferentes ciências, "uma nova e notável percepção do fenômeno (do) religioso...". ${ }^{35}$ Para as ciências particulares, a questão fundamental aqui é a respeito do lugar e do papel das religiões nas sociedades contemporâneas. Para alguns, há uma profunda mudança nesse contexto da própria religiosidade..$^{36}$

\footnotetext{
32 PUNTEL L. B., A filosofia como discurso sistemático, p. 115.

${ }^{33}$ PUNTEL L. B., A filosofia como discurso sistemático, 2015, p. 104.

${ }^{34}$ Cf. DUQUE J. M., Para o diálogo com a Pós-Modernidade, São Paulo: Paulus, 2016, p. 34: "À morte de Deus, anunciada ou constatada pela modernidade, sucede um avassalador regresso dos deuses".

${ }^{35}$ PUNTEL L. B., Estrutura e ser, p. 436.

${ }^{36}$ Cf. COX H., O futuro da fé, 2015, 13: "Os estudiosos da religião se referem à atual metamorfose na religiosidade com expressões como "mudança para a transcendência horizontal" ou "voltar-se para a imanência". Mas seria mais preciso enxergá-la como a redescoberta do sagrado no imanente do espiritual dentro do secular".
} 
Para filosofia se põe aqui uma questão fundamental: como interpretar o fenômeno religioso numa teoria filosófica? Ou mais concretamente ainda: "onde se deveria procurar um ou talvez o ponto de partida para a interpretação do fenômeno (do) religioso e desse modo também da história e da pluralidade das religiões? ${ }^{37}$ Negativamente, Puntel rejeita a proposta que considera o religioso um a priori próprio no sentido de uma "disposição oculta do espírito humano" (como pensa Otto) ${ }^{38}$ ou a proposta de entender o religioso como um fenômeno comparável a qualquer outro fenômeno devendo, assim, ser interpretado com algo neutro.

A proposta de Puntel é que sendo o religioso um fenômeno tipicamente humano, interpretar o religioso só é possível enquanto algo que provém de uma característica fundamental do ser humano enquanto ser espiritual, ou seja, "sua coextensividade intencional com o universo" o que significa afirmar um elemento absolutamente fundamental em sua interpretação: "o religioso sempre tem a ver com o universo, com o ser em seu todo e isto de um modo não teórico". ${ }^{39}$ "Em certo sentido, toda religião maior... comporta uma "visão da totalidade do mundo"...não se deveria subestimar o grande alcance desse fato" ${ }^{40}$ Para compreender sua proposta, faz-se necessário que reconsideremos os resultados da reflexão da Sistemática do Mundo em sua reflexão sobre o domínio fundamental de sua temática que é o domínio do mundo humano. Numa palavra, para Puntel, só é possível entender a religião a partir daquilo que constitui o elemento fundamental da espiritualidade humana: sua abertura ao todo. Considerar esta problemática constitui para Puntel o "primeiro enfoque" de uma consideração filosófica sistemática sobre a religião.

Trata-se, na consideração do mundo humano, de tematizar e reconstruir de forma sistemática, a partir dos saberes cotidianos e da contribuição das ciências, as estruturas fundamentais que expressam as determinações constitutivas do ser humano, ou seja, sua constituição ontológica específica. Numa palavra, trata-se de articular um quadro conceitual que expresse o que necessariamente ${ }^{41}$ compete ao ser humano enquanto ser humano, ou seja, aqueles elementos que o ser humano não poderia deixar de ter

\footnotetext{
${ }^{37}$ PUNTEL L. B., Estrutura e ser, p. 436.

${ }^{38}$ OTTO, R., Das Heilige. Über das Irrationale in der Idee des Göttlichen und sein Verhältnis zum Rationalen, München: Beck, (1917/2004), p. 137-141. (o número de páginas é da edição de 2004).

${ }^{39}$ PUNTEL L. B., Estrutura e ser, p. 437.

${ }^{40}$ PUNTEL L. B., Estrutura e ser, p. 436.

${ }^{41}$ Cf. PLANTINGA A, The Nature of Necessity, Oxford: University Press, 1974. KRIPKE S., Naming and Necessity, Cambridge, Mass.: Harvard University Press, 1980; Identity and Necessity, in: LOUX M. J. (org.), Metaphysics. Contemporary readings, 2001, p. 218-247. Este é o assim chamado problema do essencialismo que não pode ser enfrentado sem considerações modais. Distinguem-se dois tipos de propriedades dos objetos: as essenciais e as acidentais. Assim, "P é uma propriedade essencial a $\mathbf{x}$ se, e somente se, $\mathbf{x}$ exemplifica $\mathbf{P}$ em todos os mundos possíveis em que $\mathbf{x}$ existe". (Cf. BRANQUINHO J.M.B.V., Problemas de Metafísica logicamente disciplinada, Lisboa (mimeo), 2002, p. 157).
} 
para poder ser o que é enquanto ser humano, sua configuração própria, sua constituição ontológica e consequentemente o lugar que corresponde a esta configuração no todo.

Puntel faz neste contexto uma distinção esclarecedora para o enfrentamento desta problemática. ${ }^{42}$ Ele distingue entre os "constituintes absolutamente necessários" do ser humano que são seus constituintes "essenciais", aqueles que competem ao ser humano "simpliciter", isto é, independentemente de qualquer situação geográfica, histórica, etc., como o intelecto, a vontade e a consciência/autoconsciência. Os constituintes "relativa ou historicamente essenciais", que nunca podem faltar, mas que são dados exclusivamente com uma concretização como, por exemplo, ter um corpo que sempre pressupõe um determinado lugar, um determinado tempo, etc. e por fim, os constituintes "contingentes" que surgem historicamente e podem desaparecer historicamente, como, por exemplo, morar numa determinada rua.

Em primeiro lugar, o ser humano se manifesta como uma realidade material-orgânica e, enquanto tal, enquanto "uma parte da natureza", uma parte do universo, já que é um "corpo orgânico", marcado, portanto, por uma determinada estruturação corporal-biológica. Enquanto dimensão primeira, o corpo constitui o pressuposto da consciência, da autoconsciência e da intersubjetividade humanas.

Um exame rigoroso do comportamento humano mostra, no entanto, que alguns de seus momentos irrefutáveis não são simplesmente explicáveis material ou biologicamente ${ }^{43}$ e não se situam, portanto, num horizonte restrito $^{44}$. Seus atos manifestam a capacidade, de que é detentor, de se distanciar do mundo e de si mesmo e de ampliar com isto as possibilidades que lhe são abertas. Suas interrogações, que atingem em princípio tudo, revelam que ele não vive simplesmente na imediatidade uma vez que pode em princípio ir além da imediatidade de suas intuições por questionar tudo e com isto erguer-se acima de tudo numa reflexão radical sobre tudo, distanciar-se, "descolar-se" de tudo inclusive de si mesmo, de suas representações, motivações, seus impulsos, padrões de comportamento etc. Este alargamento constitui precisamente a potencialidade do

\footnotetext{
${ }^{42}$ PUNTEL L. B., Estrutura e ser, p. 363-364.

${ }^{43}$ Como diz Anzenbacher, o cérebro é órgão da sensorialidade e enquanto tal é fundamento da vida espiritual, mas não se identifica com ela. Cf. ANZENBACHER A., Introdução à Filosofia Ocidental, Petrópolis: Vozes, 2009, p. 142: “...a vida espiritual, isto é, subjetivo-autoconsciente, racional-conceitual, totalizante e linguística é, certamente, fundada sensorialmente e confere ao vivenciar sensorial uma qualidade subjetiva-autoconsciente, porém deve ser essencialmente distinta da sensorialidade".

${ }^{44} \mathrm{O}$ que não só aponta para uma outra dimensão, mas ao mesmo tempo mostra, como diz Hengstenberg, que o ser humano já é biologicamente autônomo frente ao animal. Ele possui uma biologia especificamente humana. CF. HENGSTENBERG H. E., Philosophische Anthropologie, Stuttgart: Kohlhammer, 4a. ed 1983.
} 
que chamamos o "espírito humano" ou "inteligência" em sentido estrito enquanto faculdade de referência ao mundo ilimitado, abrangente (a mesma potencialidade diz respeito à vontade e a à consciência/autoconsciência como constitutivos absolutamente necessários do ser humano).

Assim, compete ao ser humano enquanto ser espiritual uma "coextensividade intencional com o universo" ou com o Ser como aquele "todo que abrange simplesmente tudo" ${ }^{45}$, não só com o universo existente, pois a potencialidade do espírito vai além do existente na medida em que inclui todas as potencialidades dos infinitos outros universos não realizados precisamente enquanto são inteligíveis. Está em jogo aqui, portanto, não simplesmente o mundo enquanto "meio ambiente" como é o caso dos animais, mas do mundo abrangente, do mundo enquanto tal. A "intencionalidade irrestrita" se mostra, assim, como a estrutura espiritual fundamental, o traço absolutamente central do ser humano enquanto ser espiritual e como tal ela é algo ontológico, uma dimensão do mundo abrangente, portanto, um fenômeno real. Neste sentido, o ser humano não é simplesmente um ente no mundo (na totalidade dos entes), mas do Mundo (com maiúscula para significar o abrangente último em distinção do mundo enquanto a totalidade dos entes contingentes); ele é parte integrante do Mundo. Há, portanto, uma unidade fundamental que subjaz à distinção entre ser humano e o mundo, por isto se fala do Mundo ou do Ser primordial como a dimensão abrangente que abarca tanto o mundo objetivo como o mundo humano.

É a partir daqui que se pode compreender que a pertença do ser humano à esfera do ser biológico é de certo modo paradoxal: por um lado, ele é portador de uma determinação biológica como qualquer ente orgânico; por outro, está para além de qualquer determinação no sentido de que, através da pergunta, transcende a esfera do imediato e se afasta de tudo. Esta foi a razão que levou M. Scheler a caracterizar o ser humano como aquele ser que em princípio é capaz de dizer não, sendo assim o eterno protesto contra a simples efetividade. ${ }^{46}$

Por esta razão se pode e deve dizer que com isto emerge algo especificamente humano e que assim se começa a delinear a grandeza ontológica específica do ser humano e seu lugar no universo. Ele se revela como o ente que, enquanto capaz de se distanciar de tudo inclusive de si mesmo, pode tomar tudo como seu objeto inclusive a si mesmo. $\mathrm{O}$ ser subjetivo se revela coextensivo com o todo, inserido no todo, determinado pelo todo, mas constitucionalmente aberto a este todo por ser a instância que diz, que exprime, que articula o todo, a esfera da revelação da inteligibilidade universal; portanto, a instância que tudo situa na esfera do sentido (aqui

\footnotetext{
${ }^{45}$ PUNTEL L. B., Estrutura e ser, p. 367.

${ }^{46}$ SCHELER M., Die Stellung des Menschen im Kosmos, 11a. ed., Bonn, 1988, p. 55.
} 
o sentido semântico), na esfera da verdade e o que lhe torna possível distanciar-se de tudo através da reflexão crítica, ou seja, ele é um ente essencialmente capaz de reflexão. A razão humana, como a linguagem, tem uma relação reflexiva com seus limites, porque precisamente em virtude de sua reflexividade ela tem conhecimento de seus limites, exprime-os e os constata. Ora, os limites não poderiam ser indicados se o para além do limite já não estivesse desde sempre presente. ${ }^{47}$ Numa palavra, não se pode pensar o limite sem copensar o que está para além dele.

Aqui se mostra uma das diferenças fundamentais da presente reflexão para com as tendências hegemônicas na antropologia filosófica contemporânea: há nelas, na linha da famosa formulação de Heidegger, um esquecimento do Ser enquanto tal, um esquecimento da essencial abertura ao todo na consideração da determinação específica do ser do ente humano. Desta forma, pensar algo pressupõe copensar implicitamente tudo mais, já que o espírito é estruturalmente correlativo à universalidade irrestrita do Ser e isto é o que se pode chamar a "dimensão universal da subjetividade" que se caracteriza enquanto coextensividade intencional como universo ilimitado do discurso, ou seja, com a dimensão do Ser em si mesmo e em seu todo, o abarcante de tudo, a dimensão derradeira por tudo pressuposta. O círculo do espírito é o todo oniabrangente e neste sentido se pode dizer que ele se encontra em tudo que encontra, nada lhe é totalmente estranho já que tudo é inteligível. O espírito descobre em tudo o espiritual: o espírito subjetivo desvela o espírito objetivo, a racionalidade do sujeito detecta a racionalidade de todo ente, recebe o conteúdo inteligível de tudo.

Isto implica uma consequência fundamental na determinação da constituição ontológica do ser subjetivo: enquanto coextensivo com o universo ele não pode ser reduzido a um elemento que é simplesmente meio para os outros elementos do universo. Porque co-extensivo com o universo ele é, então, o "ponto de referência do universo" e, enquanto tal, não pode ser reduzido a puro meio. Ele é o ente que é fim em si mesmo num sentido estritamente ontológico. Para exprimir esta realidade a tradição empregou o conceito de "pessoa". Que o ser humano não seja tratado como fim em si mesmo se contrapõe à sua constituição ontológica equivalendo, portanto, a uma degradação ontológica.

Assim, o ser humano enquanto ser espiritual é total no sentido de coextensivo ao Ser e com isto "eu livre" na medida em que transcende tudo, não está preso por nenhum ente particular enquanto tal e isto constitui a condição de possibilidade de seu relacionamento com os entes. Desta forma, o ser subjetivo, afirmando-se como ser espiritual, ou seja, como

${ }^{47}$ HEGEL G. W. F., Enzyklopädie der philosophischen Wissenschaften 1830, 1959, § 60, p. 84; Wissenschaft der Logik I, 1967, p. 113-116. 
conhecimento (ser para a verdade, para o acolhimento do ser) e liberdade (ser para o bem, para o valor, para o consentimento ao ser) só se compreende adequadamente enquanto correlação ao todo. Enquanto tal, o ser humano não pode ser pensado e reduzido a uma entidade simplesmente física, ${ }^{48}$ pois a co-extensividade com o todo está para além de tudo o que identificamos como realidade física. Precisamente a partir daqui se determina o lugar específico que o ser humano ocupa no sistema do universo, ou seja, a posição absolutamente única que ele ocupa enquanto ser coextensivo com o universo. Não pode por isto ser reduzido à tese do que se convencinou chamar de "visão psicológica", articulada desde J. Locke e hoje muito difundida, que afirma que a identidade pessoal depende somente da consciência ou das memórias, crenças ou preferências do indivíduo. ${ }^{49}$

Uma vez trabalhada a questão das características fundamentais do indivíduo humano enquanto ser pessoal, que assim se revela uma configuração de fatos primos, põe-se a questão fundamental de sua unidade. O central nesta problemática é a questão do ponto de unidade: “...a configuração que constitui o indivíduo humano como pessoa humana se apresenta, numa primeira aproximação, como o ponto de intersecção de todos os fatos primos mencionados ou das formas às quais eles devem ser associados", isto é, todos esses fatos primos se encontram em um ou dentro de ou como um ponto no qual consiste a unidade do indivíduo ou da pessoa". ${ }^{50}$ Este fato configurador é o "dizer eu" entendido em seu caráter ontológico enquanto derivado das primeiras características essenciais, a inteligência, a vontade e a consciência/autoconsciência, que são fundamentalmente coextensividade intencional com o universo ou com o Ser em seu todo.

A tese fundamental de Puntel é, então, que o fenômeno religioso só pode ser explicado a partir do fato de que a coextensividade intencional com o universo, que caracteriza o espírito humano enquanto tal, não se reduz para os entes humanos simplesmente a uma dimensão abstrata, mas antes diz respeito concretamente, especialmente no aspecto prático, ao todo de suas vidas em suas diferentes características, ou seja, o ente humano tende a entender em sua vida concreta a posição que ele ocupa no universo e articular uma forma correspondente à sua vida através da referência explícita a este espaço abrangente entendendo-o como uma inteligência suprema derradeira e vontade suprema derradeira. A expressão desta experiência suprema assume as mais diferentes formas o que revela a grande diversidade das religiões através do tempo.

\footnotetext{
${ }^{48}$ PUNTEL L. B., Estrutura e ser, p. 374 e ss.

${ }^{49}$ Cf. a respeito da exposição e críticas às propostas contemporâneas desta posição: VIANA W. C., Metafísica da pessoa, 2019, p. 110-112, p. 121-146.

${ }^{50}$ PUNTEL L. B., Estrutura e ser, p. 367.
} 


\subsection{Interpretação filosófica da dimensão última referida pela religião}

Essas diferenças de interpretação "daquilo que se pode denominar a dimensão derradeira ou suprema no espaço intencional universal" ${ }^{11}$ levantam para a filosofia uma tarefa irrecusável que constitui o "segundo enfoque" do enfoque sistemático visado por Puntel na consideração filosófica do fenômeno religioso: esclarecer a partir de si mesma a dimensão última ou suprema antes mencionada como o ponto de referência fundamental e absolutamente central da religião. A maneira como a filosofia interpreta esta dimensão é simplesmente decisiva para toda a interpretação filosófica do fenômeno religioso. Puntel distingue aqui duas maneiras de realizar esta interpretação: ${ }^{52}$ uma é a forma direta que consiste em esclarecer o fenômeno religioso enquanto tal sem tematizar qualquer pressuposição o que para ele é enormemente problemático precisamente porque trabalha implicitamente com pressuposições fundamentais não tematizadas e analisadas. A segunda maneira mediada ou indireta constitui precisamente a sua proposta sistemática de filosofia que contém aqui dois momentos: o primeiro consiste em apresentar os traços básicos de uma teoria universal, ou seja, do Ser em seu todo que é o quadro indispensável para a articulação fundada dos discursos religiosos sobre Deus, expressão utilizada pelas religiões para designar a inteligência suprema e a vontade suprema.

\subsubsection{A metafísica primordial enquanto teoria do ser em si mesmo}

A tarefa última, então, da metafísica especial, em sequência às teorias dos diferentes domínios do mundo, como foi visto, diz respeito à interconexão de todos os campos do universo e suas estruturas específicas. Todos eles são campos de entes o que significa dizer que o que há de comum em todos esses campos é que todos "são", todos são entes. Ser é aqui caracterizado como ser dos entes, pensado precisamente como conectividade dos entes. Se Ser é o que todos os entes têm em comum, ele não pode ser um ente. Puntel denomina ser neste contexto de "ser objetivo" (entitatividade) no sentido de que aqui ser significa a interconexão ou a unidade das estruturalidades dos entes. Neste nível, portanto, o Ser se revela como a conexão ou a unidade de todos os campos dos entes e das estruturas que o constituem. Desta forma é fundamental a distinção rigorosa entre o ser no sentido objetivo e o Ser (por isto escrito em maiúscula) no sentido da dimensão originária e universal que abrange os dois polos, a interconexão de todas as interconexões, a mais abrangente das temáticas filosóficas", ${ }^{53}$

${ }^{51}$ PUNTEL L. B., Estrutura e ser, p. 437.

${ }^{52}$ Cf. PUNTEL L. B., Estrutura e ser, p. 438.

${ }^{53}$ PUNTEL L. B., Ser e Deus, p. 187. 
assim, o dado supremo, o maior tema de uma teoria filosófica. Puntel articula três vias de acesso à dimensão universal do Ser. ${ }^{54}$

Aqui é o lugar, no desdobramento da teoria filosófica, em que se põe uma pergunta inevitável: como pensar a interconexão de todas as estruturas e a dimensão do ser objetivo, os dois polos da relação?, ou seja, como pensar a interconexão entre todos esses campos especificamente estruturados (a dimensão do mundo enquanto ser objetivo) e a dimensão estrutural fundamental, ou seja, como tematizar a interconexão entre pensamento/espírito/ linguagem e a dimensão do mundo/universo, os dois polos da relação? ${ }^{55}$ Essa nova conectividade é o que Puntel denomina a "dimensão do Ser original ou primordial" que designa justamente a "conectividade absolutamente abrangente e, neste sentido, absolutamente universal pressuposta em todas as atividades teóricas e práticas" ${ }^{56}$ Este é o lugar sistemático-metódico em que é introduzida e desenvolvida uma teoria do Ser no sentido primordial e que é aqui chamada metafísica em sentido estrito que se distingue rigorosamente do que na modernidade (depois de Suarez e Wolf) se chamou de "metafísica geral" com o objetivo de tematizar as características gerais de todos os entes enquanto entes, retomando a proposta aristotélica da ciência primeira enquanto ciência do ente enquanto ente.

Para Puntel, a metafísica propriamente contém duas teorias: a Ontologia que é a teoria dos entes, ou seja, as teorias dos diferentes domínios dos entes e a teoria da interconexão de todos estes domínios que ele denomina de ser objetivo ou entitatividade (Seiendheit) (na sugestão de tradução de Viana) ${ }^{57}$ ou seja, como veremos depois, trata-se aqui, extensionalmente, isto é, do ponto de vista quantitativo, da teoria da totalidade dos entes contingentes e, intensionalmente, do ponto de vista qualitativo, da conexão de todos esses entes. Ela é, assim, uma teoria que é parte da grande teoria do Ser em si mesmo e em seu todo precisamente enquanto teoria dos entes e da entitatividade; a Einailogia é a teoria do Ser em si mesmo e, portanto, além da ontologia. Para marcar a diferença, Puntel a denomina de "Metafísica Primordial, o que no título desse texto foi chamado de "Nova Metafísica".

Para a compreensão desta proposta diz Puntel, faz-se necessário em primeiro lugar explicitar um significado mínimo de Ser. Previamente ao que vai ser exposto, faz-se necessário lembrar que nada não é um conceito portador de qualquer conteúdo, mas somente uma negação. Puntel distingue duas formas de nada, uma distinção para ele não levada em consideração e que

\footnotetext{
${ }^{54}$ PIUNTEL L. B., Ser e Deus, 177 e ss.; A FILOSOFIA COMO DISCURSO SISTEMÁTICO, 2015, 108 e ss.

${ }^{55}$ VIANA W. C., A filosofia estrutural-sistemática, 2019, p. 143 e ss.

56 PUNTEL L. P., Cirne-Lima e sua rejeição do "Deus de católicos e protestantes", 2009, p. 49.

57 VIANA W. C., A filosofia estrutural-sistemática, 2019, p. 326.
} 
é, contudo, fundamental: ${ }^{58}$ nada relativo e nada absoluto. "Ser é a negação de nada, ou seja, Ser é não nada... No sentido absoluto (como nihilum absolutum), nada significa a negação não só de algo determinado, mas de absolutamente tudo, como quer que se conceba tudo"..$^{59}$

Isto significa dizer que Ser só pode ser indicado através da negação da autonegação uma vez que não há qualquer conceito mais originário que pudesse ser usado aqui, ou seja, Ser (em sentido absoluto) e ente (em sentido relativo) são os conceitos mais fundamentais que não pressupõem nenhum outro conceito e são pressupostos por qualquer outro. Assim, a teoria do Ser tematiza o dado oniabrangente, onicompreensivo, o "Grande Dado" de uma teoria filosófica, enquanto tal a dimensão pressuposta por qualquer entidade, mas que não pressupõe nada para além de si mesma. "Seu limite é o Nada absoluto, mas este não é mais que um conceito vazio". ${ }^{60}$

Nessa proposta filosófica, então, o que o filósofo, enquanto teórico, em última instância tem a esclarecer e a determinar é a conexão absolutamente universal, a conexão de todas as conexões, ${ }^{61}$ o Ser primordial que é a dimensão mais fundamental e abrangente de todas as outras além da qual não se pode ir uma vez que é pressuposto por todas as dimensões e por isto é "o característico de tudo e de cada coisa...". ${ }^{62}$ O Ser primordial é compreendido numa dupla perspectiva: em sua singularidade como Ser (Ser enquanto tal em suas características imanentes) e em sua qualidade de abranger simplesmente tudo. A explicitação desta dimensão é chamada por Puntel de "sistemática compreensiva" uma vez que está em jogo a dimensão mais profunda e fundamental da realidade. A isto se pode denominar de "metaphysica prima" enquanto "Teoria do Ser primordial", ou seja, teoria da dimensão fundamental oniabrangente.

A questão que constitui o grande empecilho para a elaboração de uma metafísica estrutural enquanto Teoria do Ser Primordial, a Einailogia, é justamente o "abismo radical" entre a dimensão do sujeito e a dimensão da realidade, entre o sujeito cognoscente e o objeto, o mundo, que deve ser visto como a grande herança que a filosofia transcendental de Kant deixou para a filosofia que vem depois dele. ${ }^{63}$ Filosoficamente há aqui uma virada fundamental: o abismo torna impossível qualquer conhecimento

${ }^{58}$ PUNTEL L. B., Estrutura e ser, p. 582, p. 593 e ss.; Ser e Deus, p. 80, 215 e s; A FILOSOFIA COMO DISCURSO SISTEMÁTICO, 107, 123, 124 PUNTEL L. B., Estrutura e ser, p. 582, 593 e ss.; Ser e Deus, p. 80, 215 e s; A FILOSOFIA COMO DISCURSO SISTEMÁTICO, p. 107, 123, 124. ${ }^{59}$ PUNTEL L. B., A FILOSOFIA COMO DISCURSO SISTEMÁTICO, 107, 130-131

${ }^{60}$ VIANA W. C., A filosofia estrutural-sistemática, 2019, 327

${ }^{61}$ A respeito das discussões na filosofia analítica contemporânea a respeito da possibilidade ou não e de sua configuração de uma teoria abrangente cf. PUNTEL L. B., Estrutura e ser, p. 560 e ss.; Ser e Deus, p. 190 e ss.

${ }^{62}$ PUNTEL L. B., A FILOSOFIA COMO DISCURSO SISTEMÁTICO, 2015, 107

${ }^{63}$ OLIVEIRA M. A. de, A Metafísica do Ser Primordial, 2019, p. 282 e ss., VIANA W. C., A filosofia estrutural-sistemática, 2019, p. 145 e ss. 
das coisas em si mesmas; ou seja, o que são os entes é uma questão sem resposta. Surge para a filosofia uma nova questão fundamental: como justificar o conhecimento humano? Que podemos conhecer validamente? No lugar de uma ontologia se põe, então, uma teoria do conhecimento como a nova filosofia primeira.

Essas posições que partem da dicotomia entre pensar e ser, isto é, que não tematizam a dimensão última, articuladas pelo pensamento transcendental em diferentes variantes, são caracterizadas por uma incorreção básica: a dimensão da subjetividade, entendida enquanto subjetividade particularista, isto é, enquanto uma pequena instância isolada é convertida no ponto de referência último e absoluto que determina todo o universo do pensamento da realidade. Esta posição é de fato incoerente e contraditória, pois, por exemplo, as ciências e a filosofia seriam empreendimentos sem sentido: que sentido teria, então, falar do mundo se em última instância este falar nada mais fosse do que a projeção de nossas representações subjetivas sobre o mundo?

A questão anunciada - como conceituar e tematizar a interconexão ou a unidade da dimensão estrutural fundamental e do ser enquanto interconexão/ unidade dos entes estruturados? - é absolutamente decisiva. Trata-se de uma interconexão/ unidade de ordem superior e para Puntel o esclarecimento desta questão exige uma referência a Heidegger. A postura de Heidegger ${ }^{64}$ nesta problemática é categórica contra a prerrogativa absoluta, conferida à subjetividade transcendental, de ser portadora exclusiva da função de constituição no conhecimento, de ser o fator determinante. O importante e decisivo neste contexto é que seu objetivo não é falar do ser no sentido objetivo, isto é, enquanto o polo contraposto à subjetividade, mas antes enquanto aquela dimensão prévia que abarca a ambos, a subjetividade e o ser enquanto o polo objetivo a ela contraposto. Justamente aqui está o ponto central de todo o pensamento heideggeriano: o levantamento da questão do Ser no sentido desta dimensão abrangente e originária. Neste sentido, a postura de Heidegger constitui uma tentativa radical de ultrapassar a filosofia moderna da subjetividade. No entanto para Puntel esta sua posição na realidade não conseguiu efetivar sua pretensão. ${ }^{65}$

Precisamente aqui se situa o pano de fundo histórico-sistemático daquilo que Puntel denomina a sistemática estrutural. A contraposição com Heidegger se manifesta aqui muito clara. Em primeiro lugar, pensando a subjetividade como "Dasein" Heidegger deixa a subjetividade completamente de lado, ao contrário de Puntel que não exclui, mas a "desapodera" na medida em que a ela não é conferida a função de determinação de tudo e consequen-

\footnotetext{
${ }^{64}$ A respeito de uma reformulação da metafísica no seguimento de Heidegger e Gadamer cf. ROHDEN L., Hermeneutics, Metaphysics, and the question of Being, 2017, p. 221-236.

${ }^{65}$ PUNTEL L. B., Ser e Deus, p. 79-144.
} 
temente o eixo central da filosofia é transferido da subjetividade para a linguagem. ${ }^{66}$ Em segundo lugar, Dasein é para Heidegger uma instância inteiramente independente de qualquer teoria, que só possui uma única coisa: a compreensão do ser. Heidegger não se pergunta o que pressupõe e implica o compreender.

Para entender a posição da filosofia sistemático-estrutural uma questão absolutamente fundamental é a questão a respeito de como devem ser compreendidas as estruturas fundamentais, condição sem a qual nada pode ser entendido. Que significa aqui descartar a compreensão da filosofia transcendental? Para Puntel, o horizonte para o enfrentamento dessa questão é a própria pergunta fundamental que abre a sistemática compreensiva: como se tem que conceituar e tematizar a interconexão ou a unidade entre a dimensão estrutural fundamental e do ser entendido como interconexão/ unidade dos entes estruturados? Isto significa, em primeiro lugar, dizer que as estruturas fundamentais não devem ser pensadas a partir da subjetividade, mas a partir desta interconexão. Que se pretende dizer com isto?

Antes de tudo, significa que a mediação para o enfrentamento da questão passou da subjetividade para a linguagem. Indispensável para a compreensão do que está aqui em jogo é para Puntel uma comparação com a postura transcendental no que diz respeito à sua interpretação das sentenças teórico-declarativas. Esta concepção se radica no princípio básico da concepção transcendental que se explicitou com toda nitidez na famosa declaração de Kant na Crítica da Razão Pura: “O Eu penso tem que poder acompanhar todas as minhas representações" ${ }^{67}$ Este princípio fundamental se articula linguisticamente através de um operador que explícita ou implicitamente é pré-posto a cada sentença teórica e que se pode exprimir assim: "a partir da perspectiva do sujeito/eu transcendental é o caso que $\mathrm{p}^{\prime \prime}$. Este operador é essencialmente restritivo já que restringe tudo à perspectiva da subjetividade transcendental e que, dessa forma, se distingue do operador teórico irrestrito "é caso que p" que não é limitado por qualquer restrição de qualquer fator. Pensa-se, portanto, aqui, a partir de um quadro teórico que é fundamentalmente determinado pela relação sujeito-objeto. A dimensão do objeto é entendida por Kant como a coisa-em-si que é declarada incognoscível. Daí o abismo entre sujeito e objeto.

Esta posição, contudo, é insustentável por conter uma incoerência interna: na medida em que se tenta articular e legitimar o próprio ponto de vista transcendental, o procedimento aqui deixa de ser transcendental uma vez que as sentenças não podem aqui ser expressas com o operador transcendental "a partir da perspectiva do sujeito transcendental", mas simplesmente com o operador irrestrito "é o caso que", pois o contrário seria um caso claro de círculo vicioso.

${ }^{66}$ PUNTEL L. B, Estrutura e ser, p. 146-158.
${ }^{67} \mathrm{KrV}$ B 131 
Exprimindo Kant, por exemplo, a asserção de que é necessário diferenciar entre fenômeno e coisa-em-si e de que a coisa-em-si é e se mantém inatingível pelo espírito finito, ele já está apreendendo e articulando um estado de coisas que provoca uma implosão do quadro transcendental já que aqui o estado de coisas exprime justamente a relação ou interconexão entre conhecimento e fenômeno/coisa-em-si. Ora com isto já se tematiza algo a respeito da relação/interconexão algo que, de acordo com o quadro teórico transcendental, é impossível. Articulando-se uma posição filosófica a partir apenas de um dos lados da interconexão referida entre a dimensão estrutural e a dimensão objetiva, ela descumpre sua pretensão: apreender a interconexão ou a unidade da própria relação. A articulação linguística desta interconexão ou unidade se faz em sentenças na forma de "é o caso que" em que se elimina qualquer tipo de restrição, por exemplo, sujeito, ocasiões, tempo etc. Neste sentido, a referência aqui é absoluta.

Puntel fala neste contexto de reviravolta "pós-transcendental" justamente porque aqui a linguagem é compreendida não simplesmente como um produto humano como ela foi pensada pela filosofia transcendental linguisticamente rearticulada. Por exemplo, no atual debate, as diferentes posturas ditas "antirrealistas" defendem a dependência do mundo de "nossa linguagem", mesmo que se possa admitir um mundo para além de nossa linguagem a que, contudo, não temos acesso. Assim, se contrapõem à posição dos "realistas" que defendem a independência do mundo da linguagem. A concepção da linguagem é para Puntel simplesmente decisiva na superação da dicotomia ente linguagem e mundo típica do pensamento transcendental.

A tese fundamental de Puntel é que a linguagem constitui, em última análise, a dimensão expressante do real o que é implicado na tese ontológica da expressabilidade do real enquanto pressuposto básico de qualquer empreendimento teórico uma vez que "não faria sentido fazer um enunciado científico ou filosófico sobre algo ou sobre o todo (da realidade, do Ser) se esse algo ou esse todo não fosse expressável..." (PUNTEL L.B., $S e D, 207)$ : "se o ser em sua universalidade é expressável... então a esta universalidade corresponde uma instância de sua expressão igualmente universal, uma instância expressante, a linguagem"... (OLIVEIRA M. A., A Ontologia em debate no pensamento contemporâneo, 2014, 199).

A expressabilidade, ou articulabilidade, é, assim, interpretada como uma determinação imanente e irrecusável do mundo e a instância por ela implicada enquanto instância expressante intransponível é justamente a linguagem. A linguagem, composta de símbolos linguísticos no sentido familiar, como explicitou a "virada pragmática" na filosofia analítica, é uma produção histórico-contingente dos sujeitos humanos que objetiva a comunicação entre eles. A linguagem, porém, enquanto "instância universal de expressabilidade", em sentido maximal, isto é, enquanto absolutamente 
universal na medida em que potencialmente capaz de expressar ou articular todo o universo irrestrito do discurso, não é um produto humano, mas é um momento estrutural imanente ao mundo, ao Ser em seu todo: ela constitui a instância correlata à expressabilidade do Ser enquanto tal e assim é coextensional com o Ser: a linguagem "nada mais é do que o "reverso" ou o "inverso" da expressabilidade universal do mundo". ${ }^{68}$ Desta forma, a linguagem é compreendida como instância do Ser enquanto dimensão abarcante: à expressabilidade universal do Ser corresponde a universalidade da linguagem sua instância expressante, de tal modo que linguagem e mundo se revelam como diferentes manifestações do Ser. A linguagem assim compreendida é denominada por Puntel de "linguagem originária" e é ela que ocupa a centralidade na filosofia.

O ponto determinante da mudança radical se põe precisamente aqui: enquanto instância da expressabilidade universal a linguagem é uma linguagem universal e é entendida enquanto um sistema semiótico composto de uma quantidade infinita não enumerável de expressões em que não há referência ao sujeito, elemento central numa perspectiva transcendental. ${ }^{69}$ Assim, a "nossa linguagem" de que falam os antirrealistas contemporâneos é apenas um segmento deste sistema da linguagem universal "Numa palavra, a expressabilidade universal implica uma instância expressante universal, uma linguagem universal que consequentemente tem de ter um caráter diferente da "nossa" linguagem". ${ }^{70}$

"Aqui ficam claro os dois polos da relação: pensamento/linguagem e realidade/ser, que não estão separados por um abismo, mas que demonstram uma profunda conexão...". ${ }^{71}$ Se não existe abismo entre as duas dimensões, sua diferenciação se apoia sobre uma unidade mais original, abrangente que engloba as duas dimensões diferenciadas. A tematização desta unidade originária é justamente o que constitui a Teoria do Ser. ${ }^{72}$

Alcança-se, para Puntel, com o que foi exposto, o lugar sistemático de articulação de uma teoria do Ser e mais ainda se revela que aquilo que o teórico em última instância tem que explicar é justamente a dimensão absolutamente universal, o Ser primordial. "A filosofia sistemático-estrutural tematiza de modo expresso e abrangente a questão do Ser e, desse modo, desenvolve uma metafísica primordial... Isso diferencia essa filosofia fundamentalmente da filosofia analítica como um todo". ${ }^{73}$ A melhor designação para esta interconexão ou unidade é para ele "Ser" em virtude de vários fatores, entendido aqui no sentido estrito enquanto a dimensão originária,

${ }^{68}$ PUNTEL L. B., Estrutura e ser, 2008, p. 516.

${ }^{69}$ PUNTEL L. B., Estrutura e ser, 2008, p. 497 e ss.

${ }^{70}$ OLIVEIRA M. A. de, A Ontologia em debate no pensamento contemporâneo, 2014, p. 203.

${ }^{71}$ VIANA W. C., A filosofia estrutural-sistemática, 2019, 146.

72 PUNTEL L. B., Ser e Deus, 2011, p. 177-186.

${ }^{73}$ PUNTEL L. B., A filosofia como discurso sistemático, 2015, 99. 
a dimensão última enquanto tal, a dimensão abrangente enquanto tema derradeiro para o discurso teórico. Esta dimensão abrange absolutamente tudo: o pensamento, toda a dimensão teórica, todos os campos dos entes, etc. No entanto, Puntel adverte a respeito de uma falsa concepção desta dimensão muito comum ainda em certos pensadores como se tratasse de algo para além de todo pensamento, linguagem, teoria. Na realidade a dimensão do Ser é imediatamente coarticulada em cada sentença declarativa, em cada sentença teórica.

Puntel articula a pergunta fundamental de conclusão deste nível: “O que deveria ou poderia expressar uma explicação ou (auto) explicação da dimensão do Ser?". ${ }^{74}$ A questão em jogo aqui é da tematização dos momentos estruturais imanentes ou as características imanentes do Ser. ${ }^{75}$ Ele efetiva essa tarefa através de uma reformulação da "doutrina dos transcendentais" utilizada pela tradição metafísica para explicitar as características do ente enquanto ente. A reformulação vai consistir, então, em sua reconsideração enquanto características do Ser enquanto tal.

A primeira característica imanente do Ser é a inteligibilidade absolutamente universal. ${ }^{76} \mathrm{~A}$ dimensão do Ser se revelou como a interconexão de todas as interconexões o que inclui a dimensão do espírito/pensamento/linguagem. Consequentemente é impensável que a dimensão do Ser pudesse ficar fora dessa esfera. Manifestando-se como essa constelação, a dimensão do Ser enquanto tal é acessível a pensamento/espírito/linguagem. Esse "ser acessível a" é o que precisamente constitui a inteligibilidade, o que significa dizer que o Ser enquanto tal é apreensível, entendível, cognoscível, articulável, etc. A partir de uma compreensão aprofundada da inteligibilidade chega-se às duas outras características do Ser enquanto tal.

A segunda característica é a coerência universal que é aqui entendida não simplesmente como "consistência", mas designa uma interconexão positiva. Compreender, apreender, explicar algo significa captar a interconexão em que esse algo está situado. Por isso, coerência é essencialmente sistematicidade, estruturalidade universal.

A terceira característica é a expressabilidade universal. Expressabilidade é um temo técnico para exprimir os diferentes modos de compreender, articular algo e isso é pressuposto por todo tipo de enunciado teórico que não teria o menor sentido se não fosse expressável aquilo de que se trata; numa palavra o universo do discurso implica sua expressabilidade ou articulabilidade.

\footnotetext{
${ }^{74}$ PUNTEL L. B., Ser e Deus, p. 202.

75 PUNTEL L. B., Estrutura e ser, p. 580 e ss.; A filosofia como discurso sistemático, 131 e ss.

${ }^{76}$ PUNTEL L. B., Ser e Deus, p. 208 e ss.
} 
A quarta característica se diferencia das três primeiras porque elas resultaram da explicação da dimensão do Ser enquanto tal com referência ao "intelecto" e por essa razão podem ser chamadas "características teóricas". A quarta característica explicita a dimensão do Ser enquanto tal em referência à "vontade". A grande tradição usou aqui a palavra "bom/bem" e por isso pode-se denominar a característica que resulta da referência à vontade de bondade universal.

A quinta característica como beleza e foi entendida a partir da ideia de "consonância" entre as demais características imanentes, ou seja, ela exprime a unidade ou a interconexão entre os momentos estruturais imanentes do Ser enquanto tal.

\subsubsection{A Metafísica primordial enquanto teoria do Ser em seu todo: a Metafísica Modal}

Como vimos, para Puntel, a teoria do Ser primordial ocorre em duas fases: a) Enquanto pergunta pelo Ser enquanto tal, isto é, pelas características do Ser enquanto tal; b) A pergunta pelo Ser no todo, ou seja, pergunta pelo Ser levando em consideração que a dimensão originária inclui tudo a que de alguma forma compete ser; ${ }^{77}$ ela constitui justamente a interconexão de todos os entes.

Na primeira questão está em jogo um esclarecimento do Ser primordial com o propósito de tematizar as características imanentes, os momentos estruturais, do Ser enquanto tal. Na segunda se leva em consideração que o Ser primordial é a dimensão que abarca todos os entes. Então, como compreender o Ser em sua relação com os entes e a que consequências conduz uma consideração adequada desta relação? De onde pode o filósofo encontrar inspiração para o esclarecimento desta problemática? Entre as inúmeras questões que podem ser levantadas a respeito da relação entre Ser e entes uma possui um imenso alcance metódico e programático: é a pergunta que provém da introdução das grandes "modalidades", ou seja, necessidade possibilidade, contingência. O Ser primordial é possível? contingente? necessário?

No contexto do resgate da metafísica pela filosofia analítica apareceram muitos trabalhos que retomaram de forma nova questões da metafísica da tradição. Os diferentes temas foram elaborados cada um em si mesmo sem que se articulasse uma conexão entre eles, ou seja, uma proposta fundamental de compreensão do mundo em que os diferentes temas pudessem encontrar seu lugar. Entre esses temas reapareceu o tema das

77 PUNTEL L. B, Estrutura e ser Estrutura e ser, 2008, p. 559. 
modalidades. Os conceitos de "necessidade, possibilidade, impossibilidade e contingência" sempre foram considerados centrais em filosofia. No século XX, a metafísica modal foi antecedida por uma "lógica modal"78 que, iniciada por Aristóteles (no De Interpretatione e nos Analytica Priora ) e desenvolvida na Idade Média, teve no século $X X^{79}$ um extraordinário desenvolvimento. ${ }^{80}$

Um aspecto relevante aqui é a "semântica da lógica modal". ${ }^{81}$ Faz-se necessário distinguir uma semântica puramente lógica ou formal e uma semântica filosófica. No caso da "semântica formal", o objetivo é essencialmente definir a validade das sentenças lógico-modais e suas relações. Na lógica proposicional não-modal isso é feito através das tabelas de verdade; o que não é possível na lógica modal uma vez que essa lógica não é verofuncional, ou seja, ela não possui operadores com funções de verdade. Surgiram, então os diferentes sistemas que articularam respostas diferentes e não equivalentes à questão em jogo. Isso fortaleceu a ideia de não existir rigor nas linguagens modais, o que conduziu um certo ceticismo em relação às noções modais e sua consequente eliminação de uma metafísica séria.

No entanto, houve reações e Kripke é aqui uma figura central. Ele introduziu, para realizar esta tarefa, o conceito de "mundos possíveis" que para ele significa uma generalização de situação contrafactual que "é uma situação que por definição ocorre em um mundo possível diferente do atual" ${ }^{83}$ Esse conceito, na modernidade, havia sido fundamental na articulação da metafísica enquanto metafísica modal no pensamento de Leibniz, mas foi praticamente ignorada até a metade do século $X X$, uma vez que as modalidades são hoje normalmente entendidas como algo linguístico (de dicto) e não ontológico (de re).

No entanto, "a introdução da semântica dos mundos possíveis na interpretação dos sistemas modais permitiu uma uniformização do campo modal, pois para todos os sistemas modais a estratégia leibniziana impõe o uso dos operadores modais como quantificadores sobre mundos possíveis...O

\footnotetext{
${ }^{78}$ A respeito de uma reformulação por A. Plantinga do argumento ontológico da tradição baseado no sistema S5 da lógica modal cf. PLANTINGA A., The Ontological Argument_from St. Anselm to Contemporary Philosophers, London/Melbourne: Macmillan, 1968; The Nature of Necessity, Oxford: University Press, 1974. GOMES N., O argumento ontológico de Plantinga, in: Veritas 56 (2011) p. 47-63.

${ }^{79}$ Pode-se considerar Lewis como uma figura que de certa forma iniciou a formação da lógica modal contemporânea. Cf. LEWIS C.I./LANGFORD C.H., Symbolic Logic, New York: Dover Publications, 2ª ed., 1959.

${ }^{80}$ COPELAND B. J., The Genesis of Possible World, 2002, 99-137.

${ }^{81}$ PUNTEL L. B, SeD, 210

${ }^{82}$ MENZEL Chr., Possible Worlds, in: Stanford Encyclopedia of Philosophy, 2016.

${ }^{83}$ BARROSO C., A crítica de Kripke às teorias descritivistas de nomeação, in: Perspectiva Filosófica, vol. II n. 38, 2012, p. 113.
} 
desenvolvimento da semântica dos mundos possíveis inaugurou uma nova era na história da lógica modal" ${ }^{84}$

A "semântica filosófica", no entanto, objetiva ir além da formal. As discussões sobre a semântica de Kripke sobre os mundos possíveis conduzem à articulação de uma dimensão metafísica e, assim, a uma metafísica modal que se interroga não apenas sobre "o que" as coisas são, mas também sobre o "modo" como as coisas são. ${ }^{85}$

A Metafísica modal de Kripke é uma decorrência de sua posição em relação à filosofia da linguagem e à lógica modal. A questão fundamental de Kripke, pensando o real numa perspectiva modal, vai consistir em repensar modalmente as propriedades. Isto significa que ele implicitamente pressupõe o esquema da metafísica de objetos, propriedades e relações e se propõe ampliar a concepção das propriedades situando-as no seio de uma teoria das modalidades, embora o que aqui é trabalhado possa ter aplicações em ontologias que não assumem este quadro teórico. Neste contexto, ele faz uma distinção de suma importância: ${ }^{86}$ a distinção entre propriedades metafisicas e propriedades epistêmicas. ${ }^{87}$

As propriedades "metafísicas" dizem respeito à constituição ontológica dos objetos: as propriedades "necessárias" - aquelas que um objeto tem necessariamente em todos os mundos possíveis - , as propriedades que um objeto não pode deixar de ter sem deixar de ser ele mesmo, e as propriedades "contingentes", aquelas que um objeto tem que ter em pelo menos um mundo possível .Por outro lado, propriedades "epistêmicas" dizem respeito à maneira como os objetos são conhecidos: "a priori" são as que são conhecidas independentemente de investigações empíricas e "a posteriori", aquelas que só podem ser conhecidas através de investigações empíricas. ${ }^{88}$

Puntel vai atribuir às modalidades "um status fundamental tanto ontológico (e, portanto, dos entes) como específico do Ser". ${ }^{89} \mathrm{O}$ tema hoje intensivamente

${ }^{84}$ ARRUDA J. M., Mundos possíveis: realismo modal extremo e atualismo, in: IMAGUIRE G./ ALMEIDA C. L. S. de/OLIVEIRA M. A. de (orgs.), Metafísica contemporânea, Petrópolis: Vozes, 2007, p. 358.

${ }^{85}$ TOMAZ R. F., Lógicas e Metafísicas: em direção à filosofia das Galáxias, Universidade de Brasília, 2015, p. 9.

${ }^{86}$ Cf. WILLIAMSON T., Modality and Metaphysics, entrevista com Richard Marshall, https:www.3ammagazine.com/3am/Modality-and-metaphysics, acesso 24/03/2020, p. 15: "Kripke made another crucial contribution by distinguishing the sort of necessity the really matters for metaphysics from ideas like analycity, logical truth, and a a priori knowabilility". ${ }^{87}$ Para Soames esse é um dos mais importantes feitos da filosofia no século XX. Cf. SOAMES S., Kripke sobre a possibilidade epistêmica e metafísica: As duas rotas para o necessário a posteriori, in: Sképsis, ano VI, n. 9 (2013) p.160.

${ }^{88}$ Cf. KRIPKE S., Identity and necessity, 2001, p. 218-247.

${ }^{89}$ PUNTEL L. B., A filosofia como discurso sistemático, 2015, 139 Cf. KRIPKE S., Identity and necessity, 2001, p. 218-247. 
discutido sobre a designação de "mundos possíveis" é aqui considerado com o objetivo aclarar rigorosamente uma interpretação das sentenças modais. Como mostrou Menzel,$^{90}$ foram articuladas três concepções de mundos possíveis: o concretismo, o combinatorialismo e abstracionismo. Para Puntel, essa discussão é marcada por muita ambiguidade e confusão provenientes acima de tudo de uma não tematização de uma ontologia consistente. Ele apresenta os traços básicos de sua concepção de mundos possíveis de acordo com as teses fundamentais de sua concepção da filosofia estrutural-sistemática, levando em consideração sobretudo a aclaração do quadro teórico e seus componentes e sua concepção de linguagem teórica como a linguagem própria de uma reflexão filosófica. Central aqui nesse contexto é sua nova concepção da semântica e da ontologia, a semântica e a ontologia contextuais. ${ }^{91}$

Ser objetivo ou entitatividade é a dimensão que abarca todos os entes de qualquer tipo que eles sejam. Há entes reais atuais (concretos), abstratos atuais e entes positivamente puramente possíveis. O mundo atual constitui o mundo em que vivemos em que fazemos nossas experiências, em que pensamos e agimos. Esse mundo constitui o ponto de partida irrecusável de toda e qualquer atividade teórica. Dessa forma, mundos possíveis, enquanto entes puramente possíveis, portanto, entes não plenamente determinados, são configurações maximais que não são nem entes concretos nem abstratos, mas cujo status ontológico só é determinável a partir de sua relação aos entes concretos e abstratos, os entes plenamente determinados. ${ }^{92}$ Mundos positivamente possíveis não são, então, simplesmente produções do espírito humano, mas exprimem que o mundo atual poderia ter sido de outra maneira do que ele efetivamente é. É a partir dessa concepção ontológico-metafísica das modalidades que Puntel vai enfrentar a questão do segundo momento da uma teoria do Ser primordial, ou seja, a consideração do Ser em seu todo. Numa palavra, as modalidades constituem para Puntel a chave de explicação do Ser em seu todo. ${ }^{93}$

O ponto de partida da proposta reflexiva é a tese hoje muito divulgada, inclusive entre cientistas e filósofos no mais das vezes implicitamente, do "onicontingentismo": "tudo é contingente". Puntel apresenta aqui uma prova indireta, uma reductio ad absurdum, em conformidade com a figura "modus tollens". O cerne da demonstração pode exprimir-se segundo L. B. Puntel assim:

"Se tudo (o Ser como tal e em seu todo) fosse contingente, então, o nada absoluto (nihilum absolutum) seria possível. Ora, o nada absoluto não é possível. Logo, nem tudo é contingente. ${ }^{94}$

\footnotetext{
${ }^{90}$ MENZEL Chr., in: Stanford Encyclopedia of Philosophy, 2016, p. 2.

${ }^{91}$ PUNTEL L.B., Estrutura e ser, p. 243-294; A filosofia como discurso sistemático, 66 e ss.

${ }_{92}$ PUNTEL L. B., Estrutura e ser, p. 580.

${ }_{93}$ PUNTEL L. B., Ser e Deus, p. 208 e ss.

${ }^{94}$ PUNTEL L. B., Ser e Deus, p. 215.
} 
Sendo que entre contingência e necessidade não pode haver um terceiro segue-se daqui a exigência de aceitação de uma dimensão necessária do Ser. O argumento articula, assim, em primeiro lugar, uma consequência absolutamente fundamental da tese do onicontingentismo: admitir a tese de que tudo é contingente implica admitir a possibilidade do "nada absoluto", ou seja, isso significa dizer que se o Ser como tal e em seu todo fosse contingente, então, poderia ter sido que nem o Ser enquanto tal nem qualquer ente viesse a ser. "O "conceito" de nada absoluto é um "não conceito", um conceito impensável, pois ele é autocontraditório e, destarte, um pseudoconceito. Porque, caso se quisesse pensá-lo de algum modo, ...então se determinaria esse pseudoconceito de modo a mencionar um algo qualquer; porém, todo e qualquer "algo", de que natureza for, seria um determinado modo de Ser. Só é possível falar sobre o "conceito" de nada absoluto de modo paradoxal - exatamente para articular sua absurdidade".$^{95}$ $\mathrm{O}$ objetivo do argumento consiste antes de tudo em mostrar que a tese da contingência de tudo não é capaz de escapar dessa implicação, "pois, "possibilidade" sempre é "possibilidade-de-Ser"; então, é contraditório aceitar uma " possibilidade-de-Ser do nada absoluto"..${ }^{96}$

O eixo central da prova é precisamente a demonstração de que nem todas as coisas são simplesmente contingentes e por isso "o Ser inclui uma dimensão absolutamente necessária, bem como uma dimensão contingente $^{\prime \prime},{ }^{97}$ ou seja, o ponto central aqui é uma consequência simplesmente decisiva e abrangente da tese do onicontingentismo: a possibilidade do nada absoluto. Assim, uma consideração radical do Ser em si mesmo e em seu todo a partir das modalidades nos leva à compreensão de que o Ser em si mesmo e em seu todo somente é inteligível enquanto compreendido enquanto constituído bi-dimensionalmente: ele se constitui de uma "dimensão necessária" e de uma "dimensão contingente". "A comprovada bidimensionalidade da dimensão absolutamente universal do Ser constitui a base para o desenvolvimento de toda uma teoria do Ser em seu todo".$^{98}$

O argumento modal nos conduz, portanto, à afirmação incontornável de uma dimensão necessária do Ser primordial que é "absolutamente" necessária. Absoluto significa independência plena de algo distinto de si, não condicionalidade. Ora isso decorre do conceito de necessário. "Com efeito, o Ser necessário não pode a partir de si mesmo em nenhuma circunstância não ser, sendo, assim, totalmente independente do que quer que seja. Mas disto se segue que o Ser necessário não está e não pode estar condicionado por algo distinto, não sendo, assim, relativo a algo diferente. Mas é precisamente isso que o conceito de absoluto articula". ${ }^{99}$

\footnotetext{
${ }^{95}$ PUNTEL L. B., Ser e Deus, p. 217.

96 PUNTEL L. B., Ser e Deus, p. 217.

${ }^{97}$ PUNTEL L. B., A Pergunta "Por que existe alguma coisa em vez de nada" faz sentido ?, 2018, p. 43.

98 PUNTEL L. B., A filosofia como discurso sistemático, 2015, p. 141.

99 PUNTEL L. B., Ser e Deus, 2011, p. 218.
} 
Numa palavra, a experiência da contingência radical e a exigência de inteligibilidade estabelecem a mediação para a prova de uma dimensão absolutamente necessária como condição de possibilidade para a compreensão do Ser como tal e em seu todo. O Ser Primordial é Ser em plenitude, o ponto de chegada da concepção totalmente aclarada do Ser. Trata-se, então, do Ser em sentido pleno. ${ }^{100}$ Dessa forma se mostra que, o ser humano, coextensivo intencionalmente ao Ser em seu todo, é, em última instância, aberto ao Ser absolutamente necessário. Isso é simplesmente essencial para a questão do sentido na vida humana, ${ }^{101}$ para a religião ${ }^{102}$ e vale para as características absolutamente essenciais do espírito, isto é, para a inteligência, como a vontade e a autoconsciência que se põem igualmente no horizonte do Ser enquanto tal e em seu todo. Assim, a esfera da vontade é igualmente abertura à totalidade do real, portanto, em última instância ao Ser absolutamente necessário ${ }^{103}$.

Como entender, então, o Ser absolutamente necessário? Uma primeira proposta é a tese, articulada por filósofos naturalistas, de que o Ser necessário não é um ser espiritual. ${ }^{104}$ Estaríamos, então, diante de uma situação esdrúxula: entes espirituais finitos, enquanto seres espirituais, são intencionalmente coextensivos com o Ser em seu todo, consequentemente, intencionalmente coextensivos à dimensão absolutamente necessária do Ser. Se essa dimensão, então não fosse apreendida como espiritual, ela não seria coextensiva consigo mesma e muito menos com o Ser em seu todo. A tese aqui defendida pela filosofia estrutural-sistemática de que a dimensão absolutamente necessária do Ser é espiritualmente constituída, é portadora, para Puntel, de uma inteligibilidade muito superior à da tese contrária pelo menos por duas razões:

Primeiro, porque, numa perspectiva rigorosamente ontológica, a dimensão contingente é totalmente dependente da dimensão absolutamente necessária: todo seu ser depende completamente, em todos os seus aspectos, da dimensão absolutamente necessária. Como compreender, então, esta dependência se, de acordo com a proposta, o espírito finito seria portador de potencialidades que o Ser absolutamente necessário, de que ele é to-

\footnotetext{
${ }^{100}$ Cf. BOFF Cl., O Livro do Sentido, 2018, p. 493: "Há em nós um "desejo natural de sentido", e sentido pleno. Isso porque somos dotados de espírito, e espírito é abertura ao último, à plenitude, ao infinito".

${ }^{101}$ Isso é central para a problemática do sentido. Cf. BOFF Cl., O Livro do Sentido, 2018, p. 398: “Deus só pode ser o sentido absoluto se Ele existe absolutamente. Por outras: a existência do Absoluto é o pressuposto absoluto do sentido absoluto".

${ }^{102}$ Cf. VIANA W. C, A filosofia estrutural-sistemática, 2019, p. 163: "A FES não tem esta demonstração como uma prova da existência de Deus, mas o fundamento metafísico para um discurso sobre "Deus", como entendido pelas religiões".

${ }^{103} \mathrm{Cl}$. Boff fala aqui de "pulsão para o bem universal", "desejo de absoluto, de infinito". Cf. BOFF Cl., O Livro do Sentido, op. cit., p. 95.

${ }^{104}$ PUNTEL L. B., Ser e Deus, 2011, p. 231 e ss.; VIANA W. C., A filosofia estrutural-sistemática, 2019, p. 362 e ss.
} 
talmente dependente, não teria? Isto produziria entre os dois um abismo metafísico inteiramente inexplicável. ${ }^{105}$

Segundo, de acordo com a tese da expressabilidade universal do Ser, o Ser absolutamente necessário, compreendido como não espiritual, seria expressável só "em si mesmo", pois ele mesmo não captaria e articularia a si mesmo como tal, não teria, portanto, a característica fundamental do ser espiritual: a coextensividade intencional com o Ser em si mesmo e em seu todo. Dessa forma, o espírito finito possuiria um estatuto ontológico superior, porque seria expressável e expressante o que recoloca o argumento antes exposto. Portanto, a dimensão absolutamente necessária do Ser só pode ser compreendida como Ser espiritual, ou seja, como Ser dotado de inteligência, vontade e liberdade.

Precisamente enquanto contingentes, os entes contingentes não são necessariamente; sua dependência do Ser absolutamente necessário é total, ou seja, eles não são o que são a partir de si mesmos, consequentemente eles não são explicáveis a partir si mesmos. ${ }^{106}$ Então, eles vieram a ser a partir de outro fator, que só pode ser aquela dimensão de que dependem totalmente, o Ser absolutamente necessário. Sendo o Ser absolutamente necessário "Liberdade Absoluta", a dimensão contingente do Ser chegou a ser através da liberdade absoluta do Ser absolutamente necessário. "O absoluto-pôr-no-Ser-efetuado-pelo-Ser-absolutamente-necessário-livre-visando-à-dimensão contingente, no sentido esclarecido, é o que significa a ideia de criação adequadamente articulada". ${ }^{107}$ Assim, a dimensão absolutamente necessária do Ser põe no Ser a dimensão contingente do Ser como um todo. Então, "....o que surge ou é produzido no quadro ou no interior da dimensão contingente do Ser não é criado...sempre pressupõe algo precedente..." ${ }^{108}$ A relação, então, entre o criador e os entes contingentes é uma relação de "unidade". "O Ser absolutamente necessário engloba todos os entes e os inclui em si". ${ }^{109}$ Por esta razão para ele a expressão "panenteísmo", proposta pelo filósofo alemão Karl Christian Friedrich Krause no século XIX, é aqui plenamente pertinente.

\section{A consideração filosófica de Deus}

Uma vez tendo sido pensado o Ser absolutamente necessário como Ser absolutamente espiritual, pessoal e livre e como absoluto-criador o problema que se põe agora é se e como é possível avançar mais ainda na explici-

\footnotetext{
105 PUNTEL L. B., Estrutura e ser, p. 602.

106 PUNTEL L. B., A filosofia como discurso sistemático, 2015, p. 142.

107 PUNTEL L. B., Ser e Deus, 2011, p. 229.

108 PUNTEL L. B., A filosofia como discurso sistemático, 2015, p. 144.

109 PUNTEL L. B., A filosofia e a questão de Deus, in: Síntese vol. 42 n. 134, 2015, p. 392.
} 
tação de suas determinações. A questão central aqui é que a articulação de determinações ulteriores só é possível a partir de uma explicação mais determinada daquele momento central do Ser espiritual absolutamente necessário, a liberdade absoluta do absoluto criador. A pergunta, então, se articula assim: é possível explicitar mais determinadamente a liberdade absoluta? ${ }^{110}$

Neste novo nível de determinação do Ser Primordial é que a filosofia estrutural-sistemática introduz o nome "Deus", que provém justamente das tradições religiosas, na exposição filosófica. Isso significa que o processo reflexivo atingiu o "ponto" em que o termo ou respectivamente o conceito de Deus pode e tem que ser sistematicamente introduzido de modo que tenha sentido. E isto se legitima precisamente porque a determinação do Ser absolutamente necessário como criador manifesta uma grande afinidade entre o ponto que foi filosoficamente atingido e a fala religiosa de Deus que possui uma tradição antiquíssima.

Uma resposta à questão de como avançar na determinação do Ser absolutamente necessário parte do recurso a uma consideração do próprio ser humano como ser de liberdade. Como se explicitam as determinações do ser humano enquanto ser livre? A estratégia aqui é uma análise da história de suas decisões livres. Analogicamente se pode afirmar que o caminho para a explicitação das determinações mais amplas da liberdade absoluta é o mesmo: elas se explicitam através da consideração da "história" de sua liberdade. Dessa forma, não há outra possibilidade de manifestação do sentido mais determinado do Absoluto ao ser humano a não ser a de sua automanifestação na história humana.

A consequência é que a filosofia agora precisa realizar uma profunda "cesura metodológica" já que as determinações ulteriores só são explicáveis a partir de um outro quadro teórico. A filosofia aqui se lança na direção da própria história para aí recolher as tentativas de explicitação das determinações ulteriores da liberdade absoluta e neste horizonte as "religiões" se revelam como portadoras da pretensão de tematizar a automanifestação da liberdade absoluta no processo histórico. Para indicar esta fase de determinação nomeiam a realidade de que falam precisamente de Deus.

Por sua vez as teologias das diferentes religiões são neste sentido uma teoria desta determinação maior do Ser absolutamente necessário precisamente enquanto Deus, ou seja, a partir da experiência histórica dos seres humanos. No caso, por exemplo, do cristianismo, a história da liberdade absoluta é interpretada como uma autocomunicação livre de Deus enquanto história da salvação: "A partir do próprio Deus se anuncia ao homem o sentido definitivo da totalidade de sua realidade" ${ }^{111}$ A fé consiste na aceitação

${ }^{110}$ PUNTEL L. B., Ser e Deus, p. 246 e ss.

${ }^{111}$ OLIVEIRA M. A de, Mediação filosófica no trabalho teológico, 2001, p. 179. 
desse sentido que se exprime no seio da religião numa linguagem natural e teologicamente numa linguagem teórica.

Neste nível, Puntel faz duas observações fundamentais:"112 a) "A "figura concreta e determinada" da decisão livre do absoluto criador não pode ser "derivada" a priori ou como quer que seja; do contrário não se poderia falar de uma liberdade autêntica. Ela só pode ser apurada com base na história dessa liberdade"; b) Se a liberdade absoluta se manifestou ou não, só se pode saber ao analisar a história mundial; e aí o papel das religiões é fundamental.

Precisamente isso manifesta a necessidade da cesura metodológica: agora ele se dedica ao estudo da história mundial e aí, sobretudo, da história das religiões, ou seja, ele se dedica a interpretações de fenômenos históricos o que exige um método preponderantemente hermenêutico tendo como pano de fundo a postura sistemático-filosófica já tematizada, de modo particular, a filosofia da religião com seus dois enfoques.

\section{Bibliografia}

ANZENBACHER A., Introdução à Filosofia Ocidental, Petrópolis: Vozes, 2009.

ARRUDA J. M., Mundos possíveis: realismo modal extremo e atualismo, in: IMAGUIRE G. / ALMEIDA C. L. S. de / OLIVEIRA M. A. de (orgs.), Metafísica contemporânea, Petrópolis: Vozes, 2007.

BARROSO C., A crítica de Kripke às teorias descritivistas de nomeação, in: Perspectiva Filosófica, vol. II n. 38, 2012.

BOFF Cl., O livro do sentido: qual é afinal o sentido da vida (parte teórico-construtiva), Vol. II, São Paulo: Paulus: 2018.

BRANQUINHO J. M. B. V., Problemas de Metafísica logicamente disciplinada, Lisboa (mimeo), 2002.

COPELAND B. J., The Genesis of Possible World, in: Journal of Philosophical Logic, Netherlands, v. 31 n. 2 (2002) p. 99-137.

COX H., O futuro da fé, São Paulo: Paulus, 2015.

DUQUE J. M., Para o diálogo com a Pós-Modernidade, São Paulo: Paulus, 2016.

GOMES N., O argumento ontológico de Plantinga, in: Veritas 56 (2011) 47-63.

HEGEL G. W. F., Enzyklopädie der philosophischen Wissenschaften 1830, ed. por Niccolin F. /Pöggeler O, Hamburg: Meiner Verlag, 1959.

${ }_{112}$ PUNTEL L. B., Ser e Deus, 2011, p. 247. 
Wissenschaft der Logik I, ed. por Lasson G., Hamburg: Meiner Verlag, 1967.

HENGSTENBERG H.E., Philosophische Anthropologie, Stuttgart: Kohlhammer, 4a. ed., 1983.

HERRERO F. J., Ser e Deus na filosofia sistemático-estrutural de Puntel, in: Síntese v. 39 n. 124, 2012;

O desafio que a teoria sistemático-estrutural de Puntel coloca à filosofia atual, in: Kriterion n. 125 (2012).

IMAGUIRE G., Proposição, in: BRANQUINHO J. / MURCHO D./GOMES N. G. (orgs.), Enciclopédia de termos lógico-filosóficos, São Paulo: Martins Fontes, 2006, p. 628-631.

KRIPKE S., Naming and Necessity, Cambridge, Mass.: Harvard University Press, 1980;

Identity and Necessity, in: LOUX M. J. (org.), Metaphysics. Contemporary readings, London / New York: Routledge, 2001.

LEWIS C.I. / LANGFORD C.H., Symbolic Logic, New York: Dover Publications, 2a . ed., 1959.

MAC DOWELL J. A, Filosofia da Religião: sua centralidade e atualidade no pensamento filosófico, in: Interações- Cultura e Comunidade / Uberlândia / v. 6 n. 10 (2011) p. 17-49.

Religião, Modernização e Secularização, in: MAIA A. G. B. / OLIVEIRA G. P. (orgs.), Filosofia, Religião e Secularização, Porto Alegre: Editora fi, 2015, p. 30-60. MENZEL Chr., Possible Worlds, in: Stanford Encyclopedia of Philosophy, 2016.

OLIVEIRA M.A. de, Mediação filosófica no trabalho teológico, in: A Filosofia na crise da modernidade, São Paulo: Loyola, 3a . Ed, 2001.

A Ontologia em debate no pensamento contemporâneo, São Paulo: Paulus, 2014.

A Metafísica do Ser Primordial. L. B. Puntel e o desafio de repensar a metafísica hoje, São Paulo: Loyola, 2019.

PENCO C., Introdução à filosofia da linguagem, Petrópolis: Vozes, 2006.

PLANTINGA A, The Ontological Argument from St. Anselm to Contemporary Philosophers, London / Melbourne: Macmillan, 1968.

The Nature of Necessity, Oxford: University Press, 1974.

PUNTEL L. B., Estrutura e ser. Um quadro referencial teórico para uma filosofia sistemática. São Leopoldo: Ed. Unisinos, 2008.

Cirne-Lima e sua rejeição do "Deus de católicos e protestantes" e afirmação do "Deus imanente dos místicos" - um exame crítico das suas críticas e interpretações decorrentes do seu sistema neoplatônico-neohegeliano, in: Síntese, Revista de Filosofia v.36, n. 114 (2009) p. 39-86.

Metaphysics - 5 Questions, in: STEGLICH-PETERSEN A., Metaphysics - 5 questions, Automatic Press / VIP, 2010.

Ser e Deus. Um enfoque sistemático em confronto com M. Heidegger, E. Lévinas e J-L Marion. São Leopoldo: Ed. Unisinos, 2011. 
A filosofia e a questão de Deus, in: Síntese vol. 42 n. 134 (2015) p. 365-395.

A filosofia como discurso sistemático. Diálogos com Emmanuel Tourpe sobre os fundamentos de uma teoria dos entes, do Ser e do Absoluto, São Leopoldo: Editora Unisinos, 2015.

A pergunta "Por que existe alguma coisa em vez de nada?" faz sentido?, in: ROHDEN L. / VALLS A. (orgs.), Entre a Filosofia Dialética e a Gestão. Festschrift em homenagem ao Pe. Marcelo Aquino, S. J., 2018, p. 17-45.

ROHDEN L., Hermeneutics, Metaphysics, and the question of Being, 2017.

SOAMES S., Kripke sobre a possibilidade epistêmica e metafísica: As duas rotas para o necessário a posteriori, in: Sképsis, ano VI, n. 9 (2013) p. 160.

SCHELER M., Die Stellung des Menschen im Kosmos, 11a. ed., Bonn, 1988.

TOMAZ R. F., Lógicas e Metafísicas: em direção à filosofia das Galáxias, Universidade de Brasília, 2015

VIANA W. C., A filosofia estrutural-sistemática. Uma análise interpretativo-sistemática, São Leopoldo: Unisinos, 2019.

VIANA W. C., Metafísica da pessoa. O problema da identidade pessoal no debate contemporâneo. Aparecida: Ideias \& Letras, 2019.

WILLIAMSON T., Modality and Metaphysics, entrevista com Richard Marshall, https:www.3ammagazine.com/3am/Modality-and-metaphysics, acesso 24/03/2020.

Endereço do Autor:

Rua Catão Mamede, 218 - Apto. 603

Aldeota

60140-110 Fortaleza - CE

manfredo.oliveira@uol.com.br 